Annelise Brox Larsen

UiT Norges arktiske universitet

\title{
Språkfagenes fremtid i et organisasjonsteoretisk perspektiv. Er det liv laga for fremmedspråk?
}

\section{Sammendrag}

I vår globaliserte verden, hvor internasjonaliseringen av stadig flere samfunnsområder krever høy språkkompetanse av innbyggerne, er språkundervisningen $i$ skolen stadig i søkelyset. At man både som barn, som elev på skolen, som student og som voksen arbeidstaker og samfunnsborger lcerer fremmede språk og er åpen for fremmede kulturer er ncermest blitt en forutsetning for å kunne ta del i samfunnslivets ulike demokratiske prosesser. Med utgangspunkt i studier av et utvalg tekster, som omhandler praksis- og styringsdokumentasjon, drøfter denne artikkelen framtidsutsiktene for fremmedspråkfagene i Norge i et organisasjonsteoretisk perspektiv. Ett diskusjonsspørsmål knytter seg til hvor mange og hvilke språkfag som vil tilbys i skolen i årene fremover. Et annet spørsmål som drøftes er om det andre fremmedspråket vil bli gjort obligatorisk for elevene. Et tredje knytter seg til tidligere introduksjonstidspunkt for opplæring $i$ andre fremmedspråk. Fra skolemyndighetenes side har en rekke tiltak vœrt iverksatt for å styrke fremmedspråkoppleringen: Fra 2010 har det vœert drevet forsøk med tidlig start i fremmedspråk på mellomtrinnet med egen lcereplan. Det vert drevet forsøk med fagintegrert opplcering (Content Integrated Language Learning, CLIL) i eksempelvis naturfag på fremmedspråk blant annet for å øke interessen blant elevene for fremmedspråk. Både i EUs og Europarådets publikasjoner trekkes plurilingualism (flerspråklighet) frem som et viktig kjennetegn ved fremtidens språksituasjon. Om dette er en realiserbar visjon som kan implementeres uten at det gjennomføres ulike stimuleringstiltak drøftes med utgangspunkt i translasjonsteori.

\section{Innledning}

Denne artikkelen drøfter ulike fremtidsscenarier for organiseringen av engelskog fremmedspråkopplæringen i den norske skolen. Med bakgrunn i organisasjonsteoretisk translasjonsteori og randomiserte studier av et utvalg nasjonal og internasjonal styrings- og praksisdokumentasjon gis det en sannsynlighetsvurdering av hva vi kan forvente oss i Norge.

Er det for eksempel slik at vi med dagens språkpolitikk kan komme til å lukke flere språkdører enn vi åpner? For hvordan kan vi se for oss at utviklingen 
for engelskfaget og de øvrige fremmedspråkfagene vil bli frem mot 2030? Vil engelsk ikke bare komme til å skygge for de andre fremmed-språkfagene, men også for norskopplæringen og for den øvrige opplæringen på morsmål? Hva vil den teknologiske utviklingen kunne komme til à bety for engelsk- og fremmedsspråkfagenes innhold, metodikk og organisering? Vil den nåværende engelskdominansen innenfor digital språkbruk øke i samme takt som nå? Og i hvilken grad vil ulike samfunnspolitiske og økonomiske endringer nasjonalt og internasjonalt påvirke organiseringen av fremmedspråkfagene? Hvordan vil utviklingen av postnasjonale samfunn som følge av økt migrasjon virke inn på disse fagene (St.meld. nr. 6 2012-2013)? Og ikke minst, hvordan vil fremtidig engelsk- og fremmedspråkundervisning påvirkes av det vi kan kalle "reformideene" om mangfold og flerspråklighet? I denne artikkelen er det dette siste spørsmålet som løftes frem og undersøkes.

I en globalisert verden med en økende grad av internasjonalisering av stadig flere samfunnsområder kreves det at man har kunnskap om flere språk enn sitt eget morsmål. Som det fremgår av Språk bygger broer. Språkstimulering og språkopplcering for barn, unge og voksne (St.meld. nr. 23 2007-2008). oppfattes det som nødvendig at man lærer om fremmede språk og er åpen for fremmede kulturer både som barnehagebarn, som elev på skolen, som student og som voksen. Skolens engelsk- og fremmedspråkundervisning legger i denne sammenheng en viktig basis ved å oppøve elevenes grunnleggende ferdigheter i det første fremmedspråket engelsk fra og med grunnskolens første trinn og i de andre fremmedspråkene (riktignok som et ikke-obligatorisk fag) på et senere stadium i skolegangen.

Fra 1500-tallet og frem til midten av 1800-tallet var det latin som dominerte den teoretiske fremmedspråkundervisningen både i Norge og ellers i Europa. Engelsk ble introdusert i norsk skole for om lag 150 år siden, i første omgang som et praktisk kommunikasjonsfag (Ytreberg, 1993). I moderne tid har norske skoler tradisjonelt tilbudt tysk og fransk som andre fremmedspråk fra ungdomstrinnet. Fra 1990-tallet har, som vi vet, først og fremst spansk og i noen grad også russisk kommet med. Fortsatt eksisterer latin og noen steder tilbys nå italiensk samt nye språkfag som arabisk, mandarin og japansk på enkelte byskoler. Det er i første rekke i byene at elevene kan velge fra et bredere spekter av språkfag. Valgfriheten har således en sentrum-periferi-dimensjon ved seg som tilsier at ungdom i utkanten til enhver tid har måttet ta det språkfaget som skolen faktisk har sett seg i stand til å tilby. Hvilke språkfag dette i realiteten har dreid seg om har i stor grad vært avhengig av hvilke lærerkrefter som allerede var ved den enkelte skole. Har skolen allerede tilsatt en lærer i for eksempel tysk eller fransk, så er det per i dag i første omgang de språkfagene som skolens personale har utdanning i som tilbys og ikke spansk, for eksempel, selv om det skulle være slik at et flertall av elevene i utgangspunktet gjerne kunne ha ønsket seg noe annet enn det skolen tilbyr. Kun et fåtall skoler driver forsøk med toveis-lyd-bildeundervisning i fremmedspråk hvor elever på små skoler knyttes 
opp mot en litt større klasse på tettstedet og får delta i undervisningen eksempelvis i tysk. Dette skjer blant annet ved noen av Tromsøs distriktskoler.

Situasjonen nå er at spansk, tysk og fransk er dominerende i norsk skole. Bare 2.1 prosent av elevene i studieforberedende utdanningsprogram har et annet språkfag, mens bare 0.4 prosent av ungdomsskoleelevene har valgt eller har muligheter for å velge noe annet enn disse tre språkfagene (Doetjes, 2013). Ett diskusjonsspørsmål knytter seg altså til hvor mange og hvilke fag som tilbys, et annet til om det andre fremmedspråket vil bli obligatorisk eller om valgfriheten opprettholdes og et tredje til hvilket introduksjonstidspunkt en velger for det andre fremmedspråket. At engelsk fortsatt vil ha en dominerende posisjon er det svært vanskelig å opparbeide seg store motforestillinger mot. I Norge handler det i større grad om hvilke krefter det er sannsynlig at vil bidra til på den ene siden å styrke, eller på den andre siden å eventuelt svekke posisjonen til andre fremmedspråk. Og det er her tilbudet av det en innenfor organisasjonsteori benevner som såkalte reformideer har betydning. Et eksempel på en slik reformide er verdien av flerspråklighet og mangfold. Denne ideen kan anses å ha særlig interesse når en skal vurdere hvordan fremmedspråkfagene kan komme til å bli organisert i fremtiden. Derfor er translasjonen, eller oversettelsen av slike ideer til mottakerfeltet, interessant å studere.

\section{Teoretisk utgangspunkt}

I en translasjonsteoretisk tilnærming har en fokus på hvordan reformideer lander i de organisasjonene som mottar dem. Translasjonsteoretikeren ser blant annet på dette mottakerfeltet og på de aktørene på tilbudssiden som bidrar til oversettelsen av ideer fra teori til praksis. Hva skjer når slike reformideer lander i skolen? Eller rettere sagt, hvordan lander disse ideene i skolen?

Det som innenfor organisasjonsteori kalles for skandinavisk neoinstitusjonalisme (Røvik, 2007) er inspirert av amerikansk neoinstitusjonalisme (Meyer \& Rowan, 1977) og som den opptatt av det de kaller en "dekopling" mellom formelle strukturer og den faktiske atferden en kan observere på ideenes mottakerside. Det vil si at en er opptatt av hva som skjer med planer og intensjoner som formuleres i overordnede planverk når de møter avtakerfeltet. En studerer de enkelte organisasjoner og de hendelser som igangsettes og som spilles ut i møtet mellom transnasjonale eksterne reformideer og den enkelte organisasjon med sine kulturelle særtrekk, sine konvensjoner, verdier og erfaringsbaserte kunnskap. Innenfor denne tradisjonen er en ikke bare interessert i hva som skjer med organisasjonen, men i like stor grad er man opptatt av hva som skjer med ideene som en følge av møtet mellom ide og organisasjon. Den skandinaviske tradisjonen støtter seg ofte metodisk på case-studier (Sahlin \& Wedlin, 2008). En er opptatt av å undersøke hvilke aktører som befinner seg i reformideenes nedslagsfelt og studerer ulike profesjonsinteressers forhold til 
ideene og deres rolle i organisasjonen og hvorvidt ideene endrer organisasjonen (Røvik, 2007, s. 37).

Slike reformideer som vi finner i vår samtid har en del sentrale felles kjennetegn. Et slikt kjennetegn dreier seg om ideenes utbredelse. Flere reformideer har oppnådd en tilnærmet global utbredelse (Czarniawska \& Sevon, 2005). Et annet viktig kjennetegn ved flere reformideer er at de ofte har en kraft i seg til å kunne føre til reelle reformer i samfunnet. Dette har gjerne sammenheng med at reformideer ikke bare oppfattes som løsninger på ulike utfordringer som samfunnet opplever. De har også preg av å fremstå som det skandinaviske organisasjonsteoretikeren ofte omtaler som tidstypiske sirkulerende problemdefinisjoner (Røvik, 1998). Det er gjerne slik at dersom en i en organisasjon kjenner seg igjen i og tar til seg eller adopterer reformideens beskrivelse av hva utfordringene består av, ja, da er en mottakelig for løsningsforslagene også. Dersom et samfunn anser reformideenes problembeskrivelse å være gyldig for sitt område, så vil man tendere mot å være i et langt mer mottakelig modus for å ta til seg eller adoptere den sirkulerende løsningen eller reformen som presenteres. Et eksempel på en slik løsning som presenteres for å øke interessen for fremmedspråkfagene er tidlig start for andre fremmedspråk. Om dette forsøket blir iverksatt som en reell reform i Norge gjenstår å se. Et tredje kjennetegn ved reformideer er tendensen til at noen av de etter en kortere eller lengre periode blir institusjonalisert. De blir tatt som en selvfølge og oppfattet som den mest effektive måten å organisere noe på. Slike reformideer blir nesten sett på som naturgitte, hvilket betyr at de blir tatt for gitt som den naturlige og tidsriktige måten å gjøre ting på. Noen reformideer blir derfor ansett som allmenngyldige og nærmest uangripelige. De blir selvbegrunnende når de oppfattes som å være "en ide hvis tid har kommet" (Czarniawska \& Joerges, 1996; Røvik, 1998). De som arbeider i det aktuelle feltet trenger ikke å bruke mange krefter på å begrunne tiltakene de iverksetter når de foreslår omorganiseringer inspirert av reformideer.

Mens begrepet reformideer betegner sirkulerende, mer eller mindre presise ideer og planer for hvordan virksomheter eller undervisning bør organiseres, brukes begrepet reform om et faktisk tiltak, et iverksatt endringsforsøk. Slik begrepet reform brukes her kan det ha varierende omfang. Det kan dreie seg om en mindre reform, som for eksempel når en på en bestemt skole forsøker å tilby et nytt språkfag, eller inkluderer naboskolens barn i videokonferanseundervisning eller tilrettelegger for utlandsutveksling. Men det kan også være snakk om langt mer dyptgripende reformer, for eksempel slike som på det tidspunktet de lanseres ofte inneholder en rekke tidstypiske reformideer (Røvik, 1998, 2007). Slike omfattende reformer gjøres i prinsippet gjeldende for alle enheter innenfor skolefeltet. Et eksempel på en slik gjennomgripende reform er kunnskapsløftet i norsk skole, som nærmest kan ses på som en pakkeløsning av tre ideer, (1) målstyring og kvalitetssikring, (2) resultatbasert ledelse og (3) sterk sentral styring kombinert med lokal autonomi. Det eksisterer svært mange 
reformideer og reformer som til sammen utgjør det totale forandringstrykket innenfor skolesektoren. I varierende grad setter disse sine avtrykk på språkpolitikken i norsk skole. En håndterbar måte å se dette sammensatte feltet på, er å klassifisere det i tre grovinndelte hovedområder. Det er a) læreplan-reformene, b) lokale skoleutviklingsprosjekt, og c) reformer som mer indirekte berører språkfagene som for eksempel tiltak for å bidra til økt integrering av innvandrere slik som beskrevet i En helhetlig integreringspolitikk (St.meld. nr. 6, 20122013).

Kunnskapsløftet, som ble innført høsten 2006 og er den hittil siste omfattende norske reform av grunn- og videregående skole, har skilt engelsk ut med egen benevnelse fra de øvrige fremmedspråkene. Riktignok har læreplanene for språkfagene gjennomgått forandringer både i 2010 og 2013, hvor de viktigste endringene er knyttet til omstruktureringen av innholdet i engelsk for yrkesfageneVg1 og Vg2 og forsøket med tidlig start for fremmedspråkene fra 2010. Ulike tiltak igangsettes og gjennomføres av myndighetene for å sikre at Kunnskapsløftet faktisk blir innført. Men det er lokale tilpasninger og dermed ulike variasjoner av læreplanene som faktisk anvendes i klasserommet. Som i skolens øvrige fag er vektleggingen av grunnleggende ferdigheter den enkeltstående reformen i Kunnskapsløftet som mottakerfeltet sannsynligvis må ta inn over seg uansett hvordan de i øvrige situasjoner forholder seg til reformen. Ellers kan ulike skoleutviklingsprosjekter og forsøk i skolen bidra til å vri innholdet i prosjektene i retninger som passer enkeltaktører og forskingsmiljøer i større grad enn at de nødvendigvis er i samsvar med styringsambisjonene hos de nasjonale skolemyndighetene. Det er minst tre grunner til å tro dette. Den første er at et forsøk ofte er en mulighet for de deltakende aktørene til å få tatt opp et bredt spekter av utfordringer som angår språkfagene spesielt, ikke bare de som er definert av myndighetene. Den andre er at reformideene fra sentral hold gjerne blir gjenstand for diskusjoner lokalt. De blir tolket og oversatt. De blir translatert og kommer i lokale versjoner som i enkelte tilfeller kan utvikle seg i forskjellig retning fra det myndighetene opprinnelig hadde tenkt seg. Hva vet vi for eksempel om arbeidsformer i andre fremmedspråk i norske klasserom? Har det blitt et praktisk fag slik læreplanen forutsetter, eller er det snarere slik at grammatikk fortsatt er den grunnleggende ferdigheten i disse språkfagene? Eller er det slik at undervisningen hegner om L97-fokuset på tverrfaglig språkundervisning (Larsen, 1999)? Slike mulige dreininger i den lokale tilpasningen gjelder selvsagt ikke bare for språkfagene. Den tredje grunnen er at slike forsøk og prosjekter ikke bare byr på et handlingsrom til å undersøke lokale problemer innenfor enkeltfag, men også en mulighet til å ta inn eller importere alternative oppskrifter og reformideer enn de som myndighetene helst vil ha innført. Hvis en driver forsøk med for eksempel CLIL (Content Integrated Language Learning), og lar samfunnsfagundervisningen foregå på engelsk for å styrke elevenes engelskkompetanse, vil en rekke spørsmål knyttet til morsmålsopplæringen melde seg. Hva vil skje med 
morsmålskunnskapen deres innenfor dette fagfeltet; hva med ordforråd innenfor de norske minoritetsspråkene samisk og kvensk i ulike fagfelt? Blir engelsk lingua franca «all over»? Selv om styrking av morsmål er en del av myndighetenes strategi, ser vi at den her faktisk kan komme i konkurranse med strategier for å øke elevenes kompetanse i engelsk.

Det finnes et stort transnasjonalt tilbud av reformideer som tilflyter skolen. Hva kjennetegner så aktørene på tilbudssiden? Mange av de aktørene som indirekte eller direkte bidrar til å forme og sette sine avtrykk på det til enhver tid gjeldene tilbudet av reformideer i norsk skole er å finne i de politiske miljøene. Blant de mest fremtredende er nasjonale politiske og administrative myndigheter. Stortinget er selvfølgelig en viktig instans, ikke minst i sitt arbeid med å utvikle og vedta de mer omfattende læreplanreformene. Dette fikk vi et eksempel på da den planlagte reformen tidlig på 2000-tallet som skulle gjøre andre fremmedspråk til et obligatorisk fag fra ungdomsskolens 8. trinn falt under voteringen i nasjonalforsamlingen.

Kirke-, utdannings- og forskningskomiteen og de politiske partiene er også sentrale aktører på tilbudssiden, og de er sannsynligvis blitt enda viktigere som diskusjonsfora og verksteder for utviklingen av skolepolitikk og utforming av skolepolitiske reformideer i takt med at skole- og utdanningsspørsmål generelt flyttes stadig høyere opp på den politiske nasjonale agendaen. Eksterne kompetansemiljøer utgjør en stadig viktigere gruppe aktører på tilbudssiden og består av ulike forsknings- og utredningsinstitusjoner og konsulentselskaper. Denne trenden illustreres for eksempel i forbindelse med innføringen av Kunnskapsløftet gjennom skoleutviklingsprosjektet Fra ord til handling i perioden 2006-2010 der i alt 114 eksterne kompetansemiljøer var involvert som partnere. Evalueringen av prosjektet antyder at disse kompetansemiljøene vel så mye som å komme med helt nye ideer, snarere fungerte som translatører, eller som tolkere som gir sitt bidrag til og dermed setter sitt preg på ideer som allerede sirkulerer i skolefeltet (Blossing, Hagen, Nyen \& Søderstrøm, 2010). Også ulike fagforeninger bidrar til å forme reformideene. Det gjelder i særlig grad Utdanningsforbundet som alene har omlag 157.000 medlemmer. Det er imidlertid grunn til å anta at de ulike arbeidstakerorganisasjonene i mindre grad selv utvikler og lanserer reformideer, men snarere responderer på ideer som kommer fra annet hold, og at de kommer med sin stillingtaken til og sine tolkinger av reformideer som andre har lansert (Røvik, 1998). På denne måten er eksempelvis Utdanningsforbundet en aktør som kanskje like gjerne er å finne på reformideenes mottakerside som på tilbudssiden. Øverste politiske ledelse, representert ved Regjeringen, Kunnskapsdepartementet og statsråden utgjør selvsagt den autoritative politiske makt i arbeidet med implementering av reformer basert på tidens reformideer. Likevel er kanskje Utdanningsdirektoratet og Fremmedspråksenteret de institusjonene som i aller størst grad preger tilbudet av reformideer i det norske skolefeltet. Denne myndigheten til å påvirke tilbudssiden kommer for en stor del av direktoratets og senterets ambisjoner om 
å lede an i nasjonale prosesser som angår henholdsvis skole- og språkutdanningspolitikk.

Vi kan se på dette som skjer i overføringen fra denne type dokumenter til faktisk aktivitet i skolen som det organisasjonsteoretikerne ser på som en form for translasjon. Hva skjer med slike reformideer fra de formuleres i ulike planverk til de eventuelt implementeres i skolen? Blir ideene oversatt til skolekonteksten og blir de faktisk tatt i bruk eller starter og stopper deres liv i planene om dem? Mislykkes implementeringen ved at det enten skjer en (1) frikopling, hvor reformideene tas inn intellektuelt sett, men ikke kommer til uttrykk i konkret handling. Eller skjer det en (2) frastøting hvor ideene tas inn og forsøkes tatt i bruk, men frastøtes (Meyer \& Rowan 1977; Scott og Meyer 1983), men at de blir lagt vekk av ulike grunner, f.eks. fagtranghet. Dette siste fikk vi et eksempel på da forsøkene på å gjøre engelsk obligatorisk i lærerutdanningen strandet i 1996. Her valgte nasjonalforsamlingen å la Kristendom med religion og livssyn bli obligatorisk for alle som skulle ta allmennlærerutdanning istedenfor engelsk, som forslaget fra Regjeringen gikk ut på. Her hadde man planlagt en reform som ikke ble noe av delvis på grunn av fagtranghet. Den nasjonale satsningen på realfag er et annet eksempel på at oppmerksomheten rundt andre fag kan føre til at språkfagene nedprioriteres. Det tidligere nevnte eksempelet med forslaget om obligatorisk fremmedspråk på ungdomstrinnet viser også at foreslåtte reformer kan frastøtes i mange ledd i beslutnings- og implementeringskjeden. Og i den ene enden av denne kjeden, i skolen, er det unge mennesker som agerer. Det er fortsatt valgfrihet knyttet til andre fremmedspråk. Elevene kan teknisk sett oppnå generell studiekompetanse uten å ha et annet fremmedspråk i tillegg til engelsk. At translasjonen av strategidokumenter, læreplaner og reformer nedover i kjeden nødvendigvis skal medføre en satsing på fremmedspråk kan på denne bakgrunn synes som nokså naivt å tro.

\section{Metodevalg}

I denne studien utgjør et knippe offentlige dokumenter som omhandler språkpolitikk nasjonalt og internasjonalt datagrunnlaget som drøftingene i denne artikkelen støtter seg til. Bakgrunnen for utvalget er at disse dokumentene mener å uttrykke noe vesentlig om politikken på dette området. Følgende dokumenter er undersøkt: 
- Strategiplan (2005-2009). Språk åpner dører. Strategi for styrking av fremmedspråk $i$

grunnoppleringen 2005-2009. Revidert utgave fra januar 2007. http://www.hiof.no/neted/upload/attachment/site/group55/UDIR_SprakA pnerDorer_07nett.pdf

- Stortingsmelding nr. 6 (2012-2013). En helhetlig integreringspolitikk. http://www.regjeringen.no/nb/dep/bld/dok/regpubl/stmeld/20122013/meld-st-6-20122013/4/3.html?id=705984

- Stortingsmelding nr. 23 (2007-2008) Språk bygger broer. Språkstimulering og språkopplæring for barn, unge og voksne.

- http://www.regjeringen.no/pages/2077013/PDFS/STM200720080023000 DDDPDFS.pdf

- Grunnskolens informasjonssystem fra Utdanningsdirektoratet (2013). https://gsi.udir.no/informasjon/apne/

- European Commision. (2014). Supporting language diversity in Europe. http://ec.europa.eu/languages/policy/index_en.htm

- EUR-Lex. (2007, 13. april). Communication from the Commission to the Council Framework for the European survey on language competences. Commision of the European Communities. http://eurlex.europa.eu/LexUriServ/LexUriServ.do?uri=COM\%3A2007\%3A0184 \%3AFIN\%3AEN\%3AHTML

- Languages for the Future. Which languages the UK needs most and why som omhandler britisk språkpolitikk for den offentlige skole og er utgitt av British Council i 2013.http://www.britishcouncil.org /sites/britishcouncil.uk2/files/languages-for-the-future-report.pdf

At akkurat dette utvalget er kommet med i denne studien betyr ikke at det ikke finnes annen dokumentasjon fra verden utenfor Europa som kan være interessant å forholde seg til. Den sentral-europeiske og britiske påvirkningen på norsk skole er vektlagt i denne studien. En fullstendig kartlegging av global språkpolitikk har ikke syntes hensiktsmessig i dette formatet siden formålet med dokumentasjonen er å sannsynliggjøre hvilke trender som gjør seg gjeldende i vår nære fremtid snarere enn å lete etter bevis for hva som kommer til å skje i fremtiden. Og det er som påpekt tidligere to trender som peker seg ut, (1) at engelsk vokser og (2) at man forsøker å motvirke dette ved å stimulere til flerspråklighet og mangfold. Dette kommer i varierende grad til uttrykk i samtlige dokumenter som er undersøkt her. I den følgende diskusjonen vil referanser til dokumentene ikke fremkomme $\mathrm{i}$ den rekkefølgen som her er presentert, men refereres til i de sammenhenger hvor de underbygger drøftingens argumentasjonsrekke. 


\section{Diskusjon}

Det kan se ut som om det i Norge gjennomføres en satsing både for å øke interessen for andre fremmedspråk og for å styrke engelskkompetansen. To trender som det i utgangspunktet kan synes som virker mot hverandre opptrer altså side om side. På den ene siden øker utbredelsen av engelsk med uforminsket styrke (Graddol, 2006). På den annen side eksisterer det motkrefter både nasjonalt og internasjonalt som forsøker å styrke vilkårene for andre språk. Både i EUs og Europarådets publikasjoner trekkes plurilingualism (flerspråklighet) frem som et viktig kjennetegn ved fremtidens språksituasjon (European Commission, 2014; EUR-Lex, 2007). Samtidig er engelsk domeneovertakelse av svært mange fagfelt, bl.a. innenfor populærkulturen, en viktig tematikk i fremtidens språkpolitikk. Til tross for ulike mer eller mindre helhjertede forsøk på å verne om nasjonalspråkets ulike diskurser innenfor en rekke fagfelt, er det for mange fag, spesielt innenfor matematisknaturvitenskapelige fag, allerede for sent. Fagspråket er for lenge siden totalt dominert av engelsk, og dette er en utvikling som det kan synes som om det er blitt altfor sent å snu. I beste fall kan denne utviklingen bremses hvis det er ønskelig med språklig diversitet innenfor ulike fagfelt. Men på sikt vil nok disse nasjonalspråkslommene måtte fremstå som tomme. Men lommene er fortsatt der, fagfolkene som har norsk som morsmål er der fortsatt, og de snakker gjerne morsmålet sitt når de snakker om andre tema utenfor fagområdene sine. Men om det lar seg gjøre å reaktivere tapt terminologi på morsmålet innenfor disse fagområdene er mer tvilsomt og ikke en tematikk som det er hensiktsmessig å gjøre til gjenstand for spekulasjoner her. I spenningsfeltet mellom nasjonalspråkbevaring og internasjonalisering ved hjelp av engelsk og andre fremmedspråk vil ulike aktører og interessegrupperinger ha varierende grad av innflytelse. I denne artikkelen hvor det organisasjonsteoretiske perspektivet er fremtredende utgjør denne problematikken en del av bakteppet som påvirker diskusjonen av hva som vil skje med engelskfaget og med de andre fremmedspråkfagene i norsk skole i fremtiden. Hvilke konsekvenser en slik situasjon kan komme til å få for organiseringen av språkfagene i fremtidens skole er fokuset her.

I EU er det Directorate General for Education and Culture som har ansvar for språkpolitikken både innenfor utdanning og generelt i samfunnet. En to-sidig målsetning om å bidra til flerspråklighet og beskytte minoritetsspråk er overordnede politiske budskap slik som det fremgår av Supporting language diversity in Europe (European Commission, 2014). Konkretiserte ambisjoner er at minst halvparten av de europeiske15-åringene skal være i stand til å ha en enkel samtale i sitt første fremmedspråk. Dette kan være en realiserbar visjon siden dette gjelder faget engelsk for nær sagt alle unntatt Storbritannina. I tallene som presenteres i Grunnskolens informasjonssystem (Utdanningsdirektoratet, 
2013) fremkommer det at det i Norge er 27 \% av 15-åringene som ikke har andre fremmedspråk. Med hensyn til videregående skole uttrykker man i EUsammenheng ikke målsetningen i form av en eventuell sluttkompetanse, men nøyer seg med å ha som målsetning at minst tre fjerdedeler av elevene bør lære to fremmedspråk (European Commision, 2014).

Både EU og Europarådet har over svært lang tid hatt fokus på viktigheten og verdien av å lære seg fremmedspråk. At alle skal kunne bruke minst to fremmedspråk i tillegg til sitt eget morsmål er en sentral ambisjon. Europarådet og EU vektlegger flerspråklighet (plurilingualism) og tidlig språklæring (early language learning). Dette utgjør de to hovedområdene som medlemslandene blir oppfordret til å fokusere på. Denne sterke vektleggingen av verdien av å tilby undervisning i flere fremmedspråk har medført at stadig flere europeiske land også har fremskyndet starttidspunktet for fremmedspråkundervisning i sine respektive skolesystem. Dette har skjedd samtidig som en har fått større oppmerksomhet rundt tidlig språklæring som forskningsområde (Young Language Learners). Når undervisningen i det førte fremmedspråket, som for de fleste lands vedkommende er engelsk, flyttes nedover i alder, har det vist seg at undervisningen i det andre fremmedspråket også starter opp tidligere enn før. Flere av de europeiske landene har igangsatt ordninger eller planlegger fors $ø \mathrm{k}$ med tidlig start slik at også undervisningen i andre fremmedspråk starter opp tidligere i skoleløpet.

I rapporten Languages for the future som ble lagt frem 20. november i fjor (British Council, 2013) skisseres utfordringer i britisk språkundervisningspolitikk. Å studere nettopp britisk språkpolitikk i tillegg til den europeiske er nyttig. Det komparative perspektivet er viktig når ståstedet er Norge og da særlig å studere utviklingen innenfor dette feltet i Storbritannia siden en her har engelsk som førstespråk og dermed får et annet perspektiv på politikken rundt hva som skal være første fremmedspråk for britiske skoleelever. For eksempel er det nå slik at arabisk rangeres som et viktigere språk enn fransk som tradisjonelt har vært første fremmedspråk for engelsk barn. Videre blir mandarin, som det største kinesiske språket, ansett som viktigere enn tysk som tradisjonelt sett er nest etter fransk i den britiske fremmedspråkporteføljen. Dette har sammenheng både med økt migrasjon til vestlige land av personer som har et av disse to verdensspråkene som morsmål, men også med behovet for kommunikasjon med viktige handelspartnere og politiske aktører. Rapporten tar til orde for at skolebarna skal eksponeres for et bredere tilbud av fremmedspråk. "The problem isn't that we're teaching the wrong languages, " sier John Worne, strategidirektør ved British Council (2013). Likevel påpeker han at det er behov for flere ungdommer som vil lære seg arabisk, kinesisk og japansk. Dette er en utvikling vi kjenner igjen i vår skole også (Doetjes, 2013). I hvert fall er dette tilfelle for kinesisk. Også innenfor høyere utdanning ser vi en styrking av nettopp disse fagene ved de store breddeuniversitetene i Oslo og ikke minst i Bergen hvor en ved Institutt for fremmedspråk tilbyr undervisning i ni språk, 
inkludert arabisk, russisk og kinesisk mandarin. Det er imidlertid interessant å merke seg at spansk ikke har den fremtredende posisjonen i engelsk språkdebatt sammenlignet med den norske.

I Språk bygger broer. Språkstimulering og språkopplcering for barn, unge og vaksne (St.meld. nr. 23, 2007 - 2008) starter en med å sitere Ludvig Wittgenstein : «Mitt språks grenser er min verdens grenser». Med et slikt filosofisk anslag fremmes norsk språkpolitikk for de nærmeste ti-år. I dette dokumentet argumenteres det også sterkt for tidlig start for andre fremmedspråk, og en viser i generelle vendinger til andrespråktilegnelsesforskningens funn knyttet til vurderingen av hva som regnes for å være et gunstig introduksjons-tidspunkt for fremmedspråk:

Lingvister mener at elever som starter med et nytt fremmedspråk på ungdomstrinnet, gjør det i en særlig utfordrende livsfase. Det gjør det ekstra krevende for norske elever at avstanden i tid fra de begynner å lære det første fremmedspråket til de begynner med det andre fremmedspråket, er hele åtte år. Med dette mønsteret går de glipp av de mange fordelene som tidligere språklæring innebærer, bl.a. en mer praktisk tilnærming til opplæringen”. (St.meld. nr. 23 2007-2008).

Reformideen om at det er bra å kunne flere språk er gjennomgående i dette dokumentet, og skolene oppfordres til å utvide tilbudet i fremmedspråk: "Hvis skolene har ressurser til det, kan de i tillegg til tysk, fransk, spansk eller russisk også tilby andre språk, også ikke-europeiske” (St.meld. nr. 232007 - 2008). I En helhetlig integreringspolitikk (St.meld. nr. 6, 2012-2013) går man litt lengre og hevder at "Regjeringen oppfordrer kommunene og fylkeskommunene til å tilby opplæring i andre fremmedspråk enn de tradisjonelle europeiske språkene”.

I de senere år har en rekke tiltak, eller reformer, blitt gjennomført for å styrke fremmedspråkkompetansen i befolkningen (Strategiplan, 2005-2009). Reformen med tidlig start for engelsk ble innført i Norge fra 1997 for førsteklassinger samtidig som skolestarten ble senket fra 7 til 6 år og grunnskolen ble utvidet til 10 år. I en periode tidlig på 2000-tallet, og fra 2010 med egen læreplan, ble det drevet forsøk med tidlig start i andre fremmedspråk på mellomtrinnet i et utvalg kommuner i Norge. Ideen om at engelsk ikke er nok har stor utbredelse i Europa (Hellekjær, 2007), og ulike tiltak for å bevare større bredde i språktilfanget i skolen kan eksemplifiseres ved innføringen av ekstra poeng for elever som har valgt fremmedspråk som programfag i videregående opplæring ved opptak til høyere utdanning. Et annet tiltak, eller reform er lettelser i nedbetaling av studielån som språkstudentene i høyere utdanning nyter godt av. Fremmedspråkopplæring kan dessuten inngå i flere utdanningsløp ved universiteter og høyskoler og ikke bare i de tradisjonelle språkstudiene. Studier av engelsk og andre fremmedspråk kan dermed videreføres på bachelor-, master- og doktorgradsnivå, enten som rene språkstudier, som lektorutdanning eller i kombinasjon med samfunnsvitenskapelige, økonomiske eller merkantile studier. For å øke interessen blant elevene for fremmedspråk har det vært drevet 
forsøk både i Norge og ellers i Europa med fagintegrert opplæring (Content Integrated Language Learning, CLIL) i eksempelvis naturfag eller samfunnsfag på fremmedspråk (Hellekjær, 2005; Hestnes, 2006). Tyske elever kan for eksempel lære om Napoleonskrigene på fransk, mens franske elever lærer om 2.verdenskrig på tysk (Kramsch, 2006). En stor del av den CLIL-inspirerte undervisningen foregår imidlertid på engelsk.

\section{Avslutning}

Denne drøftingen av språkfagenes fremtid i et organisasjonsteoretisk perspektiv viser først og fremst hvor usikker fremmedspråkfagenes fremtid i norsk skole i realiteten er. Riktignok vises det til at tiltalende reformideer om kulturelt mangfold og flerspråklighet opererer i sonen rundt og i skolepolitikken. Dette forhold kan gi lovnader om en bedret situasjon for rekrutteringen til språkfagene både i grunnutdanningen og i høyere utdanning. Noen nye fag er introdusert som for eksempel japansk og kinesisk. Og at det tilbys emner eksempelvis i brasilkunnskap ved et av landets universiteter viser også at det tenkes nytt på språkområdet ikke bare i skolen, men også innenfor høyere utdanning. Slik nytenkning kan i neste runde komme lærerutdanningen til gode. Dersom en fremtidig nedleggelse av fylkeskommunenivået i forvaltningen fører til regionalt samarbeid om videregående skoler, kan en se for seg en økt sentralisering i skolesektoren. Dette kan igjen føre til at de videregående skolene kan tilby flere språkfag fordi elevtilfanget omfatter en hel region eller landsdel og at undervisningen digitaliseres eller at noen av elevene flytter inn til byene for å få undervisning i det språket de har valgt.

Det må uansett mer til enn hederlig omtale av tyskfaget fra Jonas Gahr Støres side for å styrke fremmedspråkfagenes posisjon (Krekling, 2013). Ellers vil fremmedspråkfagene stadig komme i konkurranse med andre gode formål. Så lenge det er valgfrihet er det små muligheter for å realisere visjonen om flerspråklighet. At motivasjon for å lære andre språk alene skal få ungdommene til å vende seg mot språkfagene med fornyet interesse er tvilsomt. Til det er fagene for krevende. Selv om en velger en praktisk tilnærming fordrer språkstudier fortsatt stor vilje til praktisering og øving fra elevenes side. $\AA$ kunne hilse og telle til ti på mange språk er riktignok et uttrykk for flerspråklighet, men i første rekke er det et eksempel på kulturelt mangfold. Og selv om "Multilingualism is a core value in Europe", flerspråklighet er en kjerneverdi i Europa, i følge Communication from the Commission to the Council Framework for the European survey on language competences (EURLex, 2007) så er fremtiden for språkfagene i skolen usikker. Likevel kan vi kan slå fast at både EU og Norge har ambisjoner på vegne av ungdommene og uttrykker ønsker om språklig mangfold og en forbedring av standarden på 
språkfeltet i de forskjellige nasjonale utdanningsprogrammene. Om dette er en realiserbar visjon som en kan tenke seg implementeres uten at det gjennomføres ulike stimuleringstiltak drøftes i denne artikkelen i et translasjonsteoretisk perspektiv. Hva som vil skje med de to strategiene, (1) økt flerspråklighet og (2) $ø k t$ bruk av engelsk, i møtet med skolen, har vært drøftet ved å vurdere hvordan slike ideer gjerne blir mottatt i avtakerfeltet.

Selv om det tilsynelatende ser ut som om mange er enige om at vi skal ha mer og bedre språkundervisning så kan vi i realiteten ende opp med mindre og dårligere undervisning fordi vi introduserer andre fremmedspråk for sent, fordi vi lar det være et ikke-obligatorisk fag og fordi vi ikke innfører CLIL som en obligatorisk arbeidsform. Dersom det er større vilje blant beslutningstakerne til å øke trykket for å få gjennomført denne type tiltak, kan imidlertid fremmedspråkfagene absolutt oppnå en ny giv.

De utvalgte dokumentene som jeg har undersøkt peker alle i samme retning og viser at reformideene om mangfold og flerspråklighet står sterkt hos de ulike aktørene som forsøker å påvirke det som skjer i skolen. Men reformideene om mangfold og flerspråklighet skal altså ikke bare snakkes pent om, men oversettes til skolebruk ved at konkrete tiltak og reformer iverksettes i skolen.

\section{Litteratur}

Blossing, U., Hagen, A., Nyen, T. og Søderstrøm, Å. (2010). Kunnskapsløftet - Fra ord til handling. Fafo-rapport 2010:01. Fafo og Karlstad Universitet. Hentet 22. Januar 2014 fra http://www.fafo.no/pub/rapp/20145/20145.pdf

British Council. (2013). Languages for the Future. Which languages the UK needs most and why. Hentet 22. januar 2014 fra

http://www.britishcouncil.org/sites/britishcouncil.uk2/files/languages-for-the-futurereport.pdf

Czarniawska, B. og Sevon, G. (2005). Global ideas - how ideas, objects and practices travel in the global economy. Stockholm: Liber.

Czarniawska, B. og Sevon, G. (1996). Translating Organizational Change. Berlin: Walter de Gruyter.

Doetjes, G. (2013). Nye fremmedspråk i skolen - Sluttrapport for kinesisk- og arabiskprosjektene. I Fokus på språk. 31. Halden: Nasjonalt senter for fermmedspråk i opplæringen. Hentet fra http://fremmedspraksenteret.no/nor/fremmedspraksenteret/forskning-og-utvikling/fokuspa-sprak/fullstendig-publikasjonsliste

European Commision. (2014). Supporting language diversity in Europe. Hentet 23. januar 2014 fra http://ec.europa.eu/languages/policy/index_en.htm

EUR-Lex. (2007, 13. april). Communication from the Commission to the Council Framework for the European survey on language competences. Brussel: Commision of the European Communities. Hentet 24. Januar 2014 fra http://eurlex.europa.eu/LexUriServ/LexUriServ.do?uri=COM\%3A2007\%3A0184\%3AFIN\%3AEN \%3AHTML

Gjengedal, K. (2013). Oxford-engelsk på vikande front. Forskerforum, 10/13. s. 8-9.

Graddol, D. (2006). English Next. Why global English may mean the end of 'English as a Foreign Language’. London: British Council. Hentet 22. januar 2014 fra 
http://www.britishcouncil.org/learning-research-english-next.pdf

Hellekjær, G. O. (2005). The Acid Test: Does Upper Secondary EFL Instruction Effectively Prepare Norwegian Students for the Reading of English Textbooks at Colleges and Universities?( Doctoral thesis). University of Oslo.

Hellekjær, G. O. (2007). Fremmedspråk i norsk næringsliv - Engelsk er ikke nok. Fokus på sprak. 3/07. Halden: Fremmedspråksenteret. Hentet 24. januar 2014 fra http://www.hiof.no/neted/upload/attachment/site/group55/Fokusnr3.pdf

Kramsch, C. (2006). Culture in Language Teaching. I Andersen, H. L., Lund, K. and Risager, K. (red.) Culture in Language Learning. Aarhus: Aarhus University Press.

Krekling, D. V. (2013, 29. desember). Frankofile Støre foreslsket i tysk. NRK. Hentet 24. Februar 2014 fra http://www.nrk.no/norge/frankofile-store-forelsket-i-tysk-1.11437549

Larsen, A. B. (1999). Tverrfaglig samarbeid i Tromsø. Språk og språkundervisning. 4, 1-9. Oslo: Landslaget moderne språk.

Meyer, J. W. og Rowan, B. (1977). Intitutionalized Organizations - Formal-Structure as Myth and Ceremony. American Journal of Sociology. 83(2): 340-363.

Røvik, K. A. (1998). Moderne organisasjone: Trender i organisasjonstenkningen ved tusenårsskiftet. Bergen: Fagbokforlaget.

Røvik, K.A. (2007). Trender og translasjoner. Ideer som former det 21. århundrets organisasjon. Oslo: Universitetsforlaget.

Sahlin, K., \& Wedlin, L. (2008) Circulating ideas: Imitation, translation and editing. In R.

Greenwood, C. Oliver, K. Sahlin \& R. Suddaby (Eds.2008), The SAGE handbook of organizational institutionalism (s. 218-242). Los Angeles/London, Sage.

Strategiplan (2005-2009). Språk åpner dører. Strategi for styrking av fremmedspråk $i$ grunnopplæringen 2005-2009. Oslo: Det kongelige utdanningsdepartement.

Revidert utgave fra januar 2007 hentet 24. januar 2014 fra http://www.hiof.no/neted/upload/attachment/site/group55/UDIR_SprakApnerDorer_07net t.pdf

St.meld. nr 6 (2012-2013). En helhetlig integreringspolitikk. Olso: Det kongelige barne-, likestillings- og inkluderingsdepartement. Hentet fra http://www.regjeringen.no/nb/dep/bld/dok/regpubl/stmeld/2012-2013/meld-st-620122013/4/3.html?id=705984

St.meld. nr. 23 (2007-2008) Språk bygger broer. Språkstimulering og språkopplering for barn, unge og voksne. Oslo: Det kongelige utdanningsdepartement. Hentet fra http://www.regjeringen.no/pages/2077013/PDFS/STM200720080023000DDDPDFS.pdf Utdanningsdirektoratet. (2013). Grunnskolens informasjonssystem. Hentet 21. februar 2014 fra https://gsi.udir.no/informasjon/apne/

Wilhelmsen, S. (2014, 14. januar). Disse tar en spansk en. Nordlys, s. 16-17.

Ytreberg, L. (1993). Engelsk i grunnskolen. Oslo: Tano. 